\title{
Job Polarization and Rising Inequality in the Nation and the New York- Northern New Jersey Region
}

\author{
Jaison R. Abel and Richard Deitz
}

\begin{abstract}
Since the 1980s, employment opportunities in both the United States and the New York-northern New Jersey region have become increasingly polarized. While technological advances and globalization have created new jobs for workers at the high end of the skill spectrum and largely spared the service jobs of workers at the low end, these forces have displaced many jobs involving routine tasks - traditionally the sphere of middle-skill workers. Moreover, these same forces have pushed up wages for high-skill workers disproportionately, contributing to increased wage inequality. The rise in inequality has been especially sharp in downstate New York and northern New Jersey, where the wage gap is now markedly larger than in the nation.
\end{abstract}

0 ver the past three decades, the United States has seen substantial growth in both high-skill and low-skill jobs, while the growth of middle-skill jobs has stagnated. During the same period, the gap in wages between the jobs that pay the most and those that pay the least has widened. This combination of trends, often referred to as job polarization, is happening in much of the developed world. ${ }^{1}$

Changes in technology and globalization appear to be the driving forces behind job polarization. Through automation and the substitution of relatively low-cost labor from other countries, these forces have displaced a range of jobs involving routine tasks that have historically been held by middle-skill workers. These same forces have increased employment opportunities for high-skill workers, particularly those who create technology or utilize it to become more productive. At the low end of the skill spectrum, many service jobs requiring physical proximity or face-to-face contact have been insulated from these forces.

In this issue of Second District Highlights, we explore the phenomenon of job polarization in the U.S. economy and examine how it has played out in the New York-northern New Jersey region. We first consider the fundamental causes of job polarization, giving particular attention to the role of technological change and globalization. We then highlight the nature and extent of job polarization in the United States, as well as in New York and northern New Jersey. We find that job polarization has been significant in each of these places, and has contributed to a rise in wage inequality in the nation and in the region. However, these effects have not been uniform: Owing in part to differences in the pattern of job polarization, inequality has risen more rapidly in downstate New York and northern New Jersey than in the nation, but somewhat more slowly in upstate New York. We conclude with a discussion of the

\footnotetext{
${ }^{1}$ For example, using data on sixteen European countries, Acemoglu and Autor (2011) show that job polarization has been even more pronounced in the European Union than in the United States, although there is variation across countries.
} 
challenges that job polarization has created and offer some thoughts on how workers - and policymakers — can respond.

\section{The Economic Forces behind Job Polarization}

Technological change and globalization appear to be the two main economic forces behind job polarization. ${ }^{2}$ Indeed, the computer revolution that took hold in the early 1980s and accelerated through the 1990s dramatically changed how people work. The widespread diffusion of technology in the economy created employment opportunities for many highly skilled workersparticularly for those who create technology, such as engineers and software developers, and for those who use it in their jobs, such as managers, financial analysts, and scientists.

At the same time, workers performing routine tasks - that is, tasks that are well defined and easily codified - have been increasingly displaced by technology. In the past, every manager or partner in a law firm was assigned an administrative assistant; now, with advances in technology, one administrative assistant can serve an entire department or office floor. Similarly, as the cost of technology has continued to fall, manufacturers have had an incentive to substitute machinery and other capital equipment, such as robots, for workers who perform routine tasks. By contrast, many low-skill workers, such as waiters, hairdressers, and health care aides, have been largely insulated from such displacement because personal contact is still required to perform the job.

A second key factor shaping job polarization is globalization, which has created opportunities for some workers but displaced others. Again, routine middle-skill jobs, especially in manufacturing, are particularly subject to this type of labor competition. Indeed, the availability of inexpensive labor overseas is a key factor underlying the decline in U.S. manufacturing jobs over the past three decades. By contrast, workers in jobs that require physical interaction and personal contact have been largely shielded from globalization since these jobs cannot be easily performed at a distance. For example, face-to-face contact is an important component of the job for teachers, police officers, entertainers, and nurses, while physical proximity is important for jobs that must be done on-site, such as construction, equipment repair, and building maintenance.

In addition to polarizing employment opportunities, these same economic forces have led to a widening gap in wages, pushing up wages most rapidly for those with high skills and exerting downward pressure on wages for those in the middle. This wage divide has occurred in large part because the diffusion of technology and inexpensive labor from other countries acts

\footnotetext{
${ }^{2}$ Other factors that are thought to have contributed to aspects of job polarization over this period include industrial restructuring, de-unionization, changes to executive compensation practices, and the declining real value of the minimum wage. For detailed studies of the causes and consequences of job polarization, see Autor, Levy, and Murnane (2003); Autor, Katz, and Kearney (2006); Goos and Manning (2007); Acemoglu and Autor (2011); and Firpo, Fortin, and Lemieux (2011)
}

as a substitute for the tasks performed by middle-skill workers engaged in routine tasks, putting downward pressure on their wages, while it complements the tasks performed by many high-skill workers, making these workers more productive and increasing their wages. For example, managers today can access and process vast amounts of information to help them make better decisions and coordinate activities more efficiently. Similarly, analysts, engineers, and scientists can now collect data more rapidly and make calculations not possible in the past.

Along with technology and globalization, changes in the demand for goods and services in the U.S. economy have shaped job polarization. As countries like the United States grow richer, growth in the consumption of services tends to outpace growth in the consumption of goods. Employment in the goods-producing sector is disproportionately composed of middle-skill workers, while service sector workers are concentrated at the top and bottom of the skill distribution. These patterns help explain why jobs have shifted toward the high and low ends of the skill spectrum and away from the middle. The growing demand for health care associated with the aging of the population is another example of how changing demand can further job polarization: jobs in the health care sector tend to be either relatively high skill and high wage (for example, surgeons and nurses) or relatively low skill and low wage (nurses' aides and phlebotomists). Reinforcing these demand trends is the fact that workers in the service sector are generally less susceptible to displacement by technology or global competition because their jobs typically require face-to-face interaction and physical proximity.

\section{Job Polarization in the United States}

To examine job polarization trends for the United States, we draw on U.S. Census data for the 1980-2010 period. We map each worker into one of twenty-five consistently defined occupations, and then use 2010 median wages as a proxy for skill to group these occupations into four categories: high-skill, upper-middleskill, lower-middle-skill, and low-skill. ${ }^{3}$ Chart 1 shows the occupations that are included in each skill category along with the median wage for each occupation.

The nine highest-paid occupations-including lawyers, doctors and nurses, financial managers, software engineers, and scientists-make up the high-skill group; the median wage of each occupation in this group was above $\$ 50,000$ in 2010 . These jobs tend to require cognitive skills, abstract thinking, coordination of activities, and decision making. The five lowest-paid occupationsincluding food service workers, farm hands, nurses' aides, and child care workers-compose the low-skill group, with the median wage for each of these occupations falling at or below $\$ 20,000$. These jobs tend to be insulated from the forces of technology and globalization because they typically cannot be automated, and often require personal interaction and physical proximity.

\footnotetext{
${ }^{3}$ Our classification of occupations as either high skill, middle skill, or low skill follows the convention established in the job polarization literature.
} 


\section{Classification of Occupations by Skill Group}

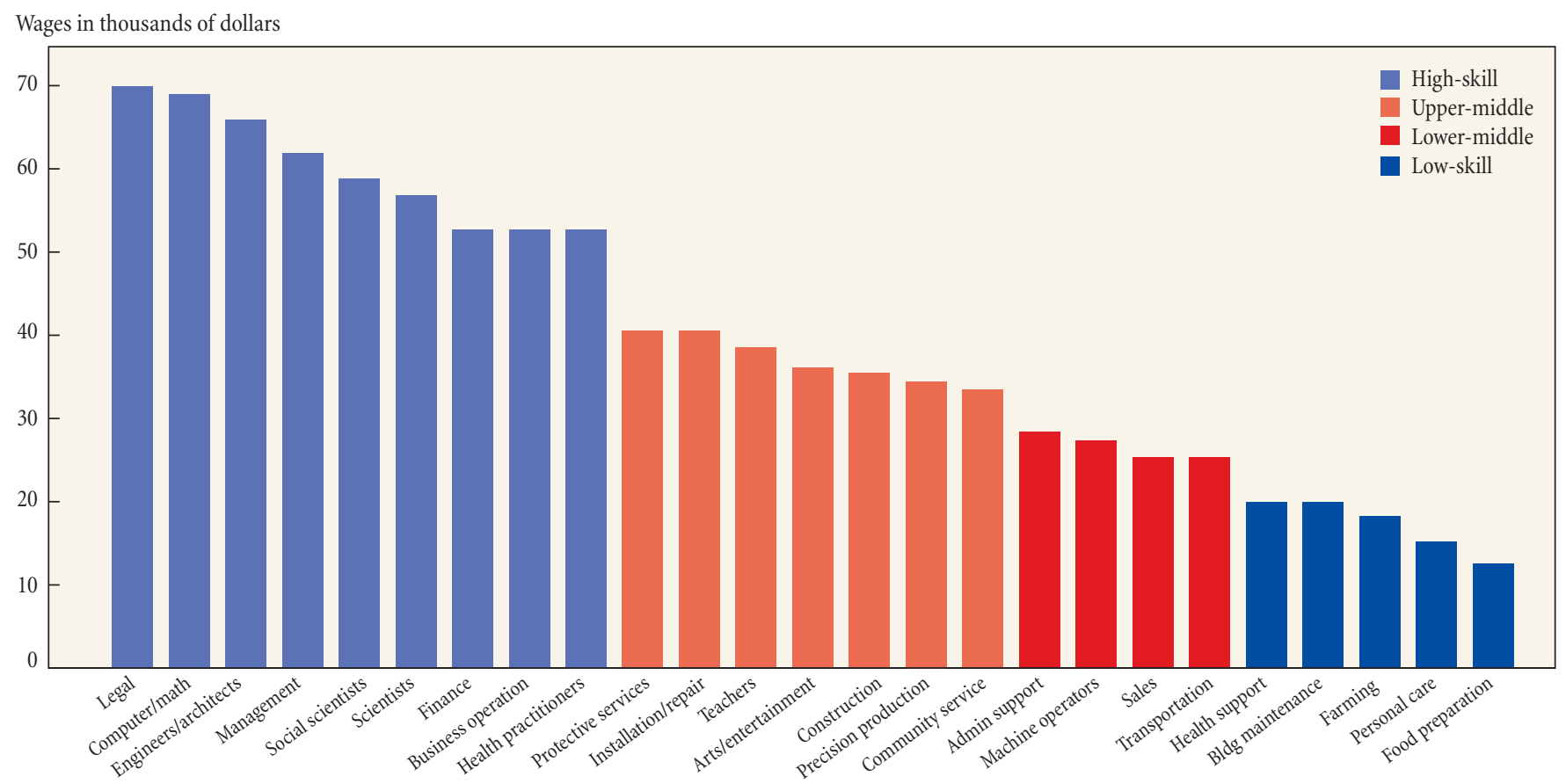

Sources: U.S. Bureau of the Census; authors' calculations.

Note: Skill groupings are based on 2010 annual median wages, which are not adjusted for hours worked.

We split middle-skill workers into two groups: upper-middle and lower-middle. The occupations in the upper-middle-skill group have median annual wages between $\$ 30,000$ and $\$ 40,000$. This group includes a mix of jobs: some that are routine and therefore subject to displacement by technology and globalization, such as precision production workers, and others that require physical proximity and are less subject to these forces, like teachers and construction workers. The lower-middle group, comprising occupations with a median wage ranging from $\$ 25,000$ to $\$ 30,000$, has a particularly high concentration of jobs that are susceptible to displacement by technology and globalization, including administrative support workers and machine operators.

\section{The Polarization of Employment}

During the 1980-2010 period, job growth in the United States occurred disproportionately at the upper and lower ends of the skill distribution, with little growth in the middle-skill groups (see the U-shaped configuration of the leftmost bars in Chart 2). Specifically, the number of jobs doubled for the high-skill group, and nearly doubled for the low-skill group. By contrast, the upper-middle group grew at a much slower rate of 46 percent, and the lower-middle group grew by just 20 percent.

Indeed, recent research indicates that employment in middleskill jobs that are routine in nature has actually fallen over the past three decades. These jobs are lost almost exclusively during recessions, and employment levels for such positions never recover once they fall. ${ }^{4}$ This trend stands in stark contrast to that for high- and low-skill jobs: these jobs show little, if any, decline during recessions and have even grown during some recessions.

The growth in high- and low-skill jobs, coupled with little growth in the middle-skill groups, has changed the composition of the workforce. The leftmost bars in Chart 3 show the share of U.S. workers in each skill category in 1980 and 2010. While both high-skill and low-skill job shares increased, the lower-middleskill group's job share shrank. In 1980, nearly half of all workers were employed in lower-middle-skill occupations. Among the occupations in this group, machine operators accounted for 10 percent of the U.S. workforce and administrative support workers accounted for 18 percent. By 2010, the share of jobs in the lower-middle group had fallen nearly 10 percentage points, with machine operators accounting for just 4 percent of all jobs and administrative support 15 percent. Over this same period, the share of high-skill jobs increased from 19 percent to 25 percent, while the share of low-skill jobs grew from 13 percent to 16 percent. The upper-middle group held steady at roughly 21 percent.

\footnotetext{
${ }^{4}$ See Jaimovich and Siu (2012) for a detailed analysis of the link between job polarization and jobless recoveries.
} 
Chart 2

Change in Employment by Skill Group, 1980-2010



Sources: U.S. Bureau of the Census; authors' calculations.

\section{The Widening Gap in Wages}

At the same time that employment has shifted toward high- and low-skill jobs and away from middle-skill jobs, the gap in wages between those at the top of the skill distribution and those at the bottom has clearly widened. As Chart 4 shows, this gap in wages has been driven primarily by relatively strong wage growth for the highest paid group.

Calculations of the percentage change in the real median wage for each skill group between 1980 and 2010 provide further evidence of this growing wage gap (Chart 5). Like employment growth, wage growth among skill groups has followed a U-shaped pattern, with high-skill and low-skill workers experiencing the most rapid increases and little, if any, growth in the middle. High-skill workers saw the largest wage gains; the median wage for workers in this group rose 37 percent between 1980 and 2010. The median wage for the low-skill group also grew, but at a much slower rate of 17 percent. The middleskill groups fared far worse. The median wage of a worker in the upper-middle group did not grow at all during the entire thirty-year period, while the median wage of a lower-middleskill worker rose just 7 percent.

As we observed earlier, the strong wage growth for high-skill workers reflects their increased productivity as technological advances and globalization have served as a complement to the tasks they perform. In addition, the supply of college graduatesperhaps the most skilled group of workers-has failed to keep pace with the growing demand for them, a trend that began in
Chart 3

Job Shares by Skill Group, 1980-2010

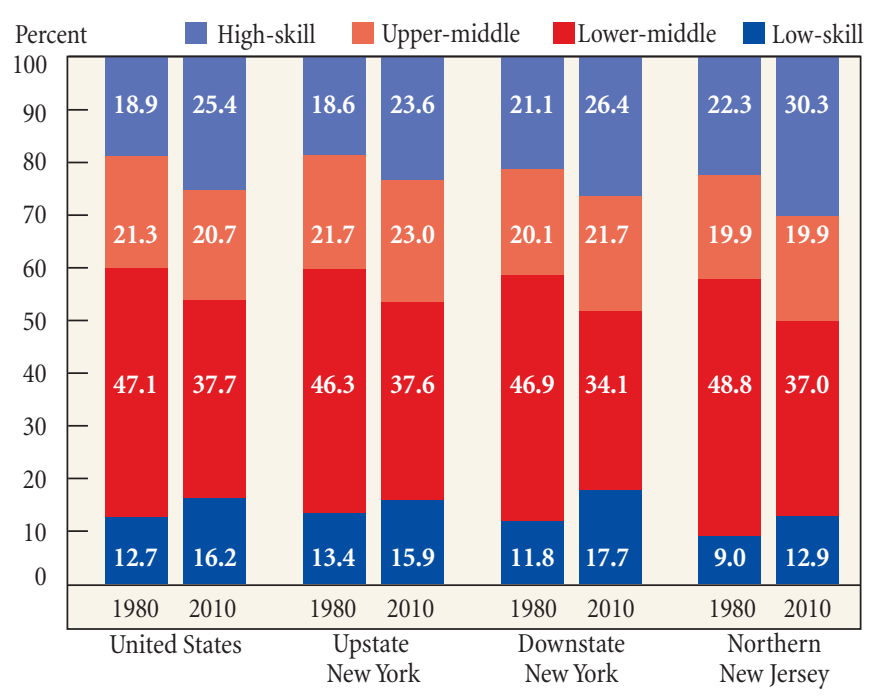

Sources: U.S. Bureau of the Census; authors' calculations.

the early 1980s. ${ }^{5}$ This shortfall has boosted the wage premium received by college-educated workers relative to those without degrees, contributing to their strong wage growth.

The expected pattern of wage growth for low-skill workers is less clear because the forces behind job polarization can affect both the supply of and demand for these workers. On the supply side, if displaced middle-skill workers begin to look for lowskill jobs, the supply of low-skill workers will increase, exerting downward pressure on the wages of this group. However, to the extent that these workers are more skilled than the average lowskill worker, their higher productivity may well warrant higher wages, increasing average wages for the low-skill group. On the demand side, strong demand for services in the U.S. economy in recent decades, stemming in part from the rapid growth in highskill workers' income, has likely increased the relative demand for low-skill workers who provide services such as child care, home cleaning, and restaurant meals, thereby putting upward pressure on their wages. Indeed, recent research has shown that wage growth among low-skill workers has been limited to those in service-oriented jobs. ${ }^{6}$ Consistent with this research, we find that wage growth within the low-skill category was strongest for personal care, food preparation, and health care support workers. Whatever dynamics may be at work, the ultimate result is clear: low-skill workers, on average, have experienced faster wage growth than middle-skill workers but slower wage growth than high-skill workers over the past three decades.

\footnotetext{
${ }^{5}$ See Goldin and Katz (2008) for a complete discussion of the relative supply and demand of college graduates in the United States.

${ }^{6}$ See Autor and Dorn (2012) for a detailed analysis of the role that low-skill service jobs have played in the polarization of the U.S. labor market.
} 
Chart 4

\section{Real Median Wage by Skill Group, 1980-2010}

Thousands of 2010 dollars

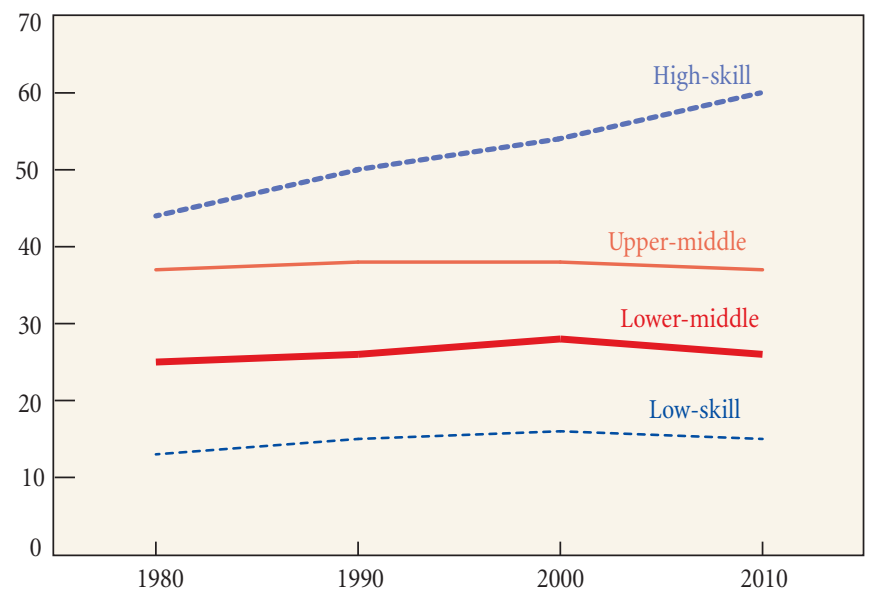

Sources: U.S. Bureau of the Census; U.S. Bureau of Labor Statistics; authors' calculations.

Note: The chart shows annual median wages, which are not adjusted for hours worked.

Job Polarization in New York and Northern New Jersey To what extent has job polarization occurred in our own region? To address this question, we identify the change in employment for each of the four skill groups in upstate New York (New York State north of Dutchess and Orange Counties), downstate New York (the remainder of New York State), and northern New Jersey. While job growth in nearly every category was slower in the region than in the nation, the same U-shaped pattern observed nationally emerges in each area. That is, the most rapid growth in jobs has occurred in the high-skill and low-skill segments of the labor market, while middle-skill groups have seen little if any growth (Chart 2). In comparing regional and national job polarization trends, we note that the relatively slow job growth across all skill groups in the region in part reflects the region's slow economic growth. The nation's population grew by 36 percent over this period, while the population of downstate New York and northern New Jersey grew 15 percent and that of upstate New York just 3 percent.

One key difference between the job growth trends in the region and nation is that while lower-middle-skill jobs grew slowly in the nation, jobs in this category actually declined in all three local areas. In large part, this difference reflects relatively steep job losses in two prominent occupations within this group: machine operators and administrative support jobs. Indeed, machine operator jobs plunged 56 percent in upstate New York and 62 percent in both downstate New York and northern New Jersey between 1980 and 2010, far larger declines than the national decline of 35 percent. While administrative support jobs grew at a slow rate of 21 percent for the nation,

\section{Chart 5}

\section{Growth in Real Median Wages by Skill Group, 1980-2010}

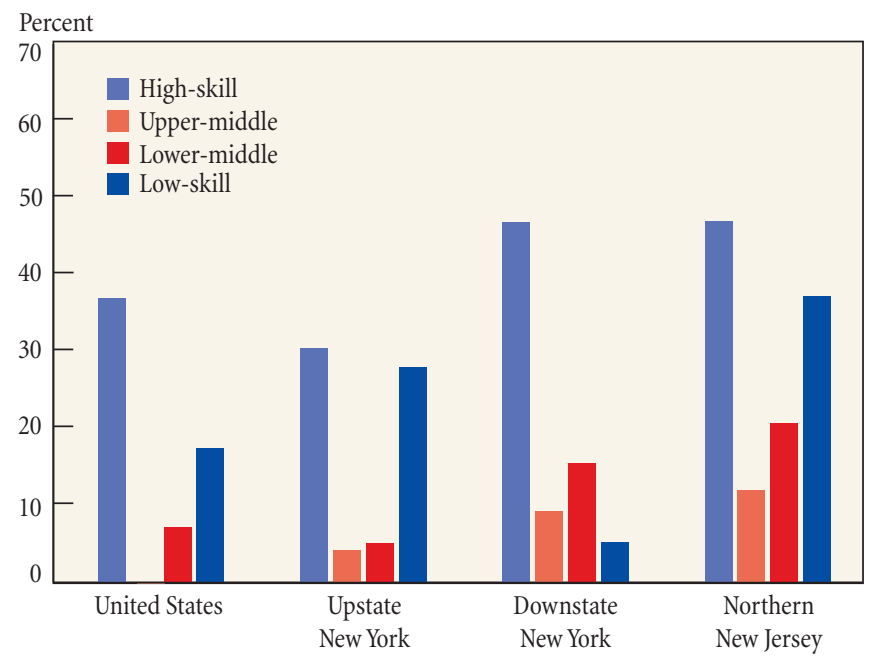

Sources: U.S. Bureau of the Census; U.S. Bureau of Labor Statistics; authors' calculations.

Note: The chart shows growth in annual median wages, which are not adjusted for hours worked.

these jobs fell 22 percent in downstate New York and 13 percent in northern New Jersey. The outsized decline likely reflects the historically large concentration of administrative support workers in the region, who served the corporate headquarters and financial services industry offices so prevalent in the downstate New York-northern New Jersey area. In 1980, administrative support accounted for about one in four jobs in New York City and one in five jobs in northern New Jersey, shares that declined to under 15 percent in both places by 2010 .

A second key difference in the job growth patterns of the nation and the region is that the skill group that grew the fastest in downstate New York and northern New Jersey was the low-skill group. In general, this expansion of low-skill jobs reflected strong growth in many service jobs, which was in turn supported by substantial income growth in and around New York City, especially for high-skill workers. This trend was not quite as significant in upstate New York, however, where wage growth was weaker than average.

These trends shifted the composition of jobs among these groups and, as in the nation, resulted in a shrinking share of workers in middle-skill occupations, while job shares grew at the upper and lower ends (Chart 3). Like the nation, each region saw the share of lower-middle-skill workers decline by roughly 10 percentage points, while high-skill and low-skill shares increased. There are, however, some differences in how the job shares among skill groups evolved over the period. 
Chart 6

\section{Index of Wage Inequality, 1980-2010}

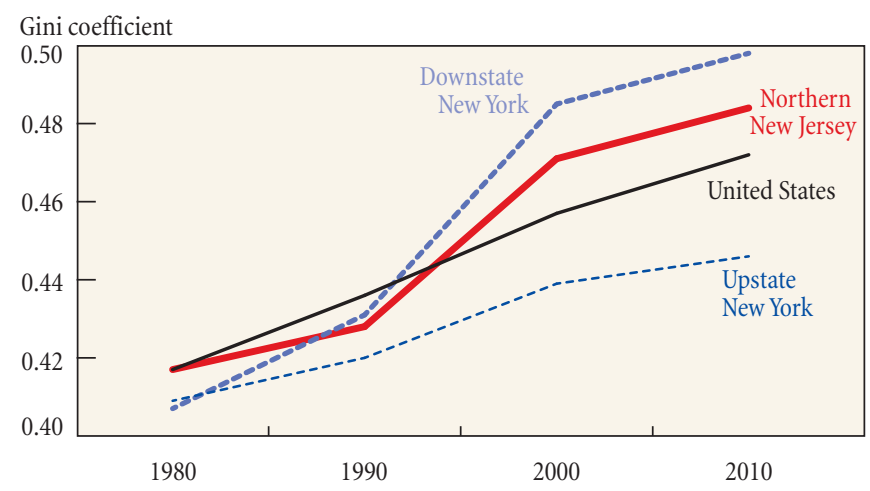

Sources: U.S. Bureau of the Census; authors' calculations.

Upstate New York did not see quite as much of an increase in the high-skill job share as the nation; in addition, unlike the nation, upstate New York saw a slight increase in the share of employment in upper-middle-skill jobs. Downstate New York saw its high-skill job share rise about five percentage points to more than 26 percent, while its low-skill job share rose much more significantly than the corresponding share for the nation, from 11.8 percent to 17.7 percent. It also saw its upper-middle job share increase slightly, while the lower-middle job share fell more steeply than the nation's, to just above 34 percent. Northern New Jersey experienced a rather sharp increase in the share of workers in high-skill jobs, from 22.3 percent in 1980 to more than 30 percent in 2010. Like the nation, it saw its low-skill job share increase about 4 percentage points, but that share remained below the national share over the period.

The polarization of wage gains in New York and northern New Jersey has also tracked that of the nation as a whole: wage gains have generally been strongest for high-skill and low-skill jobs, with wages for the middle groups growing more slowly. The U-shaped pattern is by and large present for each region, although wage growth is generally stronger across groups in downstate New York and northern New Jersey than in the nation (Chart 5). The skill group with the most rapid wage growth was the high-skill group in all three places. In downstate New York and northern New Jersey, wage growth for this group outpaced that of U.S. high-skill workers, while in upstate New York, it lagged the nation's. ${ }^{7}$ Median wages for the low-skill group grew fairly strongly as well in upstate New York and northern New Jersey, though in downstate New York, the pace was only 5 percent. This slow wage growth for low-skill workers in downstate New York

\footnotetext{
${ }^{7}$ Given the strong presence of the financial services industry, one might expect to see even higher rates of wage growth for high-skill workers in and around New York City. However, because our analysis is based on median wages rather than average wages, the impact of outliers is mitigated. In addition, our analysis of earnings growth does not include nonwage income, such as capital gains.
}

may be due in part to high immigration flows to New York City; the resulting expansion in the supply of low-skill workers would put downward pressure on their wages relative to national norms. Across the region, wage growth for middle-skill groups was generally slower than that for high- and low-skill groups.

\section{Job Polarization and Rising Inequality}

Given the patterns documented above, it should come as no surprise that job polarization has been a key contributor to rising inequality in the United States over the past three decades. The concentration of wage growth among high-skill workers, combined with disproportionate job growth at the upper and lower ends of the skill distribution, has resulted in a more unequal economic environment. But this increase in wage inequality has not been uniform across regions within the United States.

To examine trends in wage inequality for the United States and the New York-northern New Jersey region, we estimate Gini coefficients. A Gini coefficient is a common measure of inequality that ranges in value between 0 and 1 , where 0 represents perfect equality (every worker earns the same wage) and 1 represents perfect inequality (one person earns all wages). Thus, a Gini coefficient can be viewed as a summary measure of inequality among all individual workers, regardless of their jobs.

Chart 6 plots Gini coefficients for the United States, upstate New York, downstate New York, and northern New Jersey over the 1980-2010 period. Wage inequality in the United States increased steadily over this period, rising from a value of 0.42 in 1980 to 0.47 in 2010. Like the nation, the New York-northern New Jersey region experienced an increase in wage inequality over the same period. However, the rise in inequality was sharpest in downstate New York and in northern New Jersey, where inequality is now well above the U.S. level. Two factors contributed to the more rapid rise in inequality in and around New York City. First, when compared with their U.S. counterparts, high-skill workers in downstate New York saw more rapid wage growth, while low-skill workers saw slower wage growth. Second, downstate New York experienced substantial growth in its low-skill jobs. The trends in northern New Jersey were somewhat similar; here, too, the wages of workers in high-skill jobs grew relatively rapidly. By contrast, in upstate New York, the rise in inequality was slower than average, primarily because wage growth was not quite as strong for highskill workers, while the wages of low-skill workers grew more rapidly than in the nation.

\section{Conclusion}

Technological change and globalization have significantly altered the landscape of local labor markets in the United States, including those in New York and northern New Jersey. While job prospects for high-skill workers and some low-skill workers have generally improved in recent decades, job opportunities for many middle-skill workers continue to dwindle. As a result, some of the 
traditional pathways to the middle class - such as working on a factory floor upon graduation from high school-have become increasingly difficult to follow.

These trends suggest that building skills is more important for workers than ever before. For those entering the workforce, this means that the skill set they possess will greatly influence the types of jobs for which they will qualify and the wage they can expect to earn. A college education provides one clear pathway to help these workers develop the skills that are required to perform high-skill jobs. Thus, focusing on ways to make a college education more accessible and fostering the ability of students to complete their degrees - particularly in the science and technical fields, where the bulk of the high-skill job growth has been concentrated - would be beneficial. In addition, programs other than a traditional undergraduate or graduate degree may provide an alternative way to help people build skills that will be directly applicable to available jobs.

Those workers who are displaced from middle-skill jobs face a more difficult situation than those yet to enter the workforce because they often incur large and permanent wage losses and, in some cases, never fully recover from the job loss. ${ }^{8}$ Thus, determining how best to mitigate the consequences of job polarization for these workers poses a significant challenge. While there are no easy solutions to this growing problem, programs designed to help displaced workers retrain and build skills can improve both reemployment prospects and earnings potential. However, such programs vary in terms of their effectiveness, so it is important to determine how to best support programs that produce the most favorable outcomes. ${ }^{9}$

The effectiveness of educational institutions and workforce training programs can be enhanced through close ties with employers. Partnerships of this nature allow firms to communicate their needs to those who are helping people develop the necessary skills to qualify for available jobs. In turn, these

${ }^{8}$ See Couch and Placzek (2010) for more information on the earnings losses of displaced workers.

${ }^{9}$ See Jacobson, LaLonde, and Sullivan (2005) for more information on the effectiveness of retraining programs. collaborations can help educational institutions design relevant programs and identify opportunities for the people they train.

The economic forces driving job polarization have existed for decades and are likely to continue. While these forces pose many challenges, they have allowed a significant and growing number of workers to become more productive and earn higher wages. Thus, given the reduction in opportunities for middleskill workers, it is especially important to help people build the skills necessary to take on the high-skill jobs that these forces can create. Individuals, employers, educational institutions, and policymakers each have a role to play in helping the workforce adapt to this changing economic environment.

\section{References}

Acemoglu, Daron, and David H. Autor. 2011."Skills, Tasks, and Technologies: Implications for Employment and Earnings." In Orley Ashenfelter and David Card, eds., Handbook of Labor Economics, vol. 4, 1043-171. Amsterdam: Elsevier-North Holland.

Autor, David H., and David Dorn. 2012. "The Growth of Low Skill Service Jobs and the Polarization of the U.S. Labor Market.” NBER Working Paper no. 15150, April.

Autor, David H., Lawrence F. Katz, and Melissa S. Kearney. 2006. “The Polarization of the U.S. Labor Market.” American Economic Review 96, no. 2 (May): 189-94.

Autor, David H., Frank Levy, and Richard J. Murnane. 2003. “The Skill Content of Technological Change: An Empirical Exploration." Quarterly Journal of Economics 118, no. 4 (November): 1279-333.

Couch, Kenneth A., and Dana W. Placzek. 2010. "Earnings Losses of Displaced Workers Revisited." American Economic Review 100, no. 1 (March): 572-89.

Firpo, Sergio, Nicole M. Fortin, and Thomas Lemieux. 2011. "Occupational Tasks and Changes in the Wage Structure." Working paper, University of British Columbia, February.

Goldin, Claudia, and Lawerence F. Katz. 2008. The Race between Education and Technology. Cambridge, Mass.: Harvard University Press.

Goos, Maarten, and Alan Manning. 2007. "Lousy and Lovely Jobs: The Rising Polarization of Work in Britain." Review of Economics and Statistics 89, no. 1 (February): 118-33.

Jacobson, Louis S., Robert LaLonde, and Daniel Sullivan. 2005. "Is Retraining Displaced Workers a Good Investment?” Federal Reserve Bank of Chicago Economic Perspectives 29, Second Quarter: 47-66.

Jaimovich, Nir, and Henry E. Siu. 2012.“"The Trend Is the Cycle: Job Polarization and Jobless Recoveries." NBER Working Paper no. 18334, August.

ABOUT THE AUTHORS

Jaison R. Abel is a senior economist and Richard Deitz an assistant vice president in the Regional Analysis Function of the Federal Reserve Bank of New York.

Current Issues in Economics and Finance is published by the Research and Statistics Group of the Federal Reserve Bank of New York. Linda Goldberg and Thomas Klitgaard are the editors.

The content co-editor of this article is Ayşegül Şahin.

The views expressed in this article are those of the authors and do not necessarily reflect the position of the Federal Reserve Bank of New York or the Federal Reserve System. 